\title{
Brachychiton acerifolius (A.Cunn. ex G.Don) Macarthur and C. moore Leaf and Flower Extracts Inhibit the Growth of a Panel of Pathogenic Bacteria
}

\author{
Ian Edwin Cock $\mathbf{k}^{1,2, *}$ \\ 'School of Environment and Science, Griffith University, Nathan, Brisbane, Queensland, AUSTRALIA. \\ EEnvironmental Futures Research Institute, Griffith University, Nathan, Brisbane, Queensland, AUSTRALIA.
}

\begin{abstract}
Introduction: Brachychiton acerifolius (A.Cunn. ex G.Don) Macarthur and C. moore is a large tree that is native to subtropical regions of the east of Australia. Decoctions and infusions produced from the leaves of the related species Brachychiton diversifolius were used by the first Australians to treat a variety of bacterial diseases. Despite this, B. acerifolius leaf and flower extracts have not been rigorously examined for antibacterial properties against many pathogens. Methods: The antimicrobial activity of $B$. acerifolius leaf and flower extracts was investigated by disc diffusion and growth time course assays against a panel of pathogenic bacteria. The growth inhibitory activity was quantified by MIC determination. Toxicity was determined using the Artemia franciscana nauplii bioassay. Results: Methanolic $B$. acerifolius leaf and flower extracts inhibited the growth of a wide range of bacterial species. Growth of both gram positive and gramnegative bacteria was inhibited by the $B$. acerifolius leaf and flower extracts, although the gram negative bacteria were substantially more susceptible to the extracts than the gram positive bacteria were. The leaf extracts were more potent growth inhibitors than the flower extracts against all bacteria tested. The $B$. acerifolius leaf extract was a strong inhibitor of $A$. faecalis, $K$. pneumonia, P. fluorescens, S. newport, S. sonnei, B. cereus, S. aureus and $S$. pyogenes growth, with MIC values substantially $<1000 \mu \mathrm{g} / \mathrm{mL}$. The antibacterial activity of the methanolic $B$. acerifolius leaf extract was fur-
\end{abstract}

ther investigated by growth time course assays which showed significant growth inhibition in cultures of $P$. fluorsecens and $B$. cereus within $1 \mathrm{hr}$ of exposure. Both extracts were determined to be nontoxic in the Artemia franciscana nauplii bioassay, indicating their safety for internal use as well as for topical uses. Conclusion: The lack of toxicity of the $B$. acerifolius leaf and flower extracts and their growth inhibitory bioactivity against a panel of pathogenic bacteria partially validate the traditional usage of this species to treat bacterial diseases and indicates their potential in the development of antiseptic agents.

Key words: Malvaceae, Illawarra flame tree, Australian plants, Antibacterial activity, Toxicity, Medicinal plants.

\section{Correspondence:}

Dr. Ian Edwin Cock

${ }^{1}$ School of Environment and Science, Griffith University, 170 Kessels Rd, Nathan, Brisbane, Queensland-4111, AUSTRALIA.

${ }^{2}$ Environmental Futures Research Institute, Griffith University, 170 Kessels Rd, Nathan, Brisbane, Queensland-4111, AUSTRALIA.

Phone no: +61737357637

E-mail: i.cock@griffith.edu.au

DOI: $10.5530 /$ pc.2020.1.7

\section{INTRODUCTION}

In recent years, many bacterial strains have acquired resistance genes, rendering them either extremely (XDR) or totally drug resistant (TDR) to many antibiotics. ${ }^{1}$ Few therapeutic options remain to treat the diseases caused by these pathogens and this situation is likely to worsen as bacteria exchange resistance genes and more strains become multi-drug resistant (MDR). For this reason, the development of alternative antibiotic chemotherapies is considered by the World Health Organisation (WHO) to be one of the most serious challenges facing medical science. ${ }^{2}$ It is unlikely that the previous methods of antibiotic discovery/development will be as successful in the future and new therapeutic options are urgently required.

Traditional plant derived medicines are an attractive option for the development of new antibiotic therapies as they have been used for a variety of therapeutic purposes, including fighting microbial disease and their uses have often been well documented. ${ }^{3}$ Indeed, the ability of plant extracts to block the growth of pathogenic bacteria has become the focus of much recent study. ${ }^{4,5}$ Much of the research into traditional medicinal plant use has focused on Asian, ${ }^{6,7}$ African ${ }^{8-12}$ and South American ${ }^{13,14}$ plants. Similarly, the medicinal properties of Australia flora has also received recent attention. Australian Aborigines understood the therapeutic properties of a wide variety of Australian plants and how to use them effectively. ${ }^{15}$ Whilst studies have reported antibacterial activity for some Australian plant species, ${ }^{16-19}$ the antibacterial activity of many Australian native plants remains unexamined.

Brachychiton acerifolius (A.Cunn. ex G.Don) Macarthur and C. moore
(Figure 1a; Family Malvaceae; commonly known Illawarra flame tree) is a large tree that grows in subtropical regions on the east coast of Australia. It has large variable leaves, with up to 7 deep lobes (Figure 1b) which it sheds in the dry winter season. B. acerifolius produces masses of red flowers (Figure 1c) in late spring which develop into dark brown pod-like fruits up to $10 \mathrm{~cm}$ in length. The seeds are nutritious and were roasted and eaten by Aborigines. Whilst we were unable to find records of the medicinal usage of $B$. acerifolius to treat bacterial disease, the related species Brachychiton diversifolius R.Br. (commonly known as northern kurrajong) was used by the first Australians to treat wound infections, as well as diarrhoea and dysentery. ${ }^{20}$ The antibacterial activity of $B$. acerifolius is also poorly studied. However, $B$. diversifolius has been reported to have moderate growth inhibitory activity against Bacillus subtilis and Sarcina lutea. ${ }^{21}$ The same study reported that the extracts were completely ineffective against Staphylocoxccus aureus and Pectobacterium carovorum at $2000 \mu \mathrm{g} / \mathrm{mL}$. However, that study tested the bacteria against a single concentration and did not determine MIC values, making it difficult to compare the activity to that of other studies. A recent study also reported that Brachychiton rupestris (T.Mitch. ex Lindl.) K.Schum. leaf extracts are potent inhibitors of Streptococcus pyogenes growth. ${ }^{22}$

Several investigations have reported the chemical composition of $B$. acerifolius leaves and several interesting phytochemical components have been identified. The flavonoid content has been particularly well reported and apigenin-7-O-glucuronide (Figure 1d), rutin (Figure 1e), luteolin-7-O-D-glucuronide (Figure 1f), quercetin (Figure 1g), kaempferol 
(Figure 1h), luteolin (Figure 1i) and apigenin (Figure 1j) have been identified. ${ }^{23}$ Interestingly, many flavonoids (including some of those identified in that study) have good antibacterial activities ${ }^{24}$ and may give the leaves bacterial growth inhibitory properties. Despite these promising studies, the antibacterial properties and phytochemistry of the leaves from $B$. acerifolius is poorly studied. We were also unable to find any studies that tested the flowers for antibacterial activity. The current report was undertaken to screen $B$. acerifolius leaf and flower extracts for growth inhibitory properties against a panel of pathogenic bacteria.

\section{MATERIALS AND METHODS}

\section{Plant collection and extraction}

Brachychiton acerifolius (A.Cunn. ex G.Don) Macarthur and C. moore leaves and flowers were obtained from verified trees on Logan campus of Griffith University, Brisbane, Australia. The leaf and flower samples were dried in a Sunbeam food dehydrator and stored at $-30^{\circ} \mathrm{C}$. Prior to use, the dried plant materials were freshly ground to a coarse powder and $1 \mathrm{~g}$ quantities were weighed into separate tubes. A volume of $50 \mathrm{~mL}$ methanol was added to individual tubes and extracted for $24 \mathrm{hr}$ at $4^{\circ} \mathrm{C}$ with gentle shaking. All solvents were obtained from Ajax, Australia and were AR grade. The extracts were filtered through filter paper (Whatman No. 54) under vacuum and dried in an Eppendorf concentrator 5301. The resultant pellets were dissolved in $10 \mathrm{~mL}$ sterile deionised water (containing $1 \% \mathrm{DMSO}$ ). The extracts were passed through $0.22 \mu \mathrm{m}$ filter (Sarstedt) and stored at $4^{\circ} \mathrm{C}$ until use.

\section{Qualitative phytochemical studies}

Phytochemical analysis of the B. acerifolius leaf and flower extracts for the presence of phenolic compounds, flavonoids, saponins, triterpenoids, phytosteroids, cardiac glycosides, anthraquinones, tannins and alkaloids was conducted by previously described assays. ${ }^{25,26}$

\section{Antibacterial screening Test microorganisms}

All media was supplied by Oxoid Ltd., Australia. Clinical isolate microbial strains of Aeromonas hydrophilia, Alcaligenes feacalis, Bacillus cereus, Citrobacter freundii, Escherichia coli, Klebsiella pneumoniae, Proteus mirabilis, Pseudomonas fluorescens, Salmonella newport, Serratia marcescens, Shigella sonneii, Staphylococcus aureus, Staphylococcus epidermidis and Streptococcus pyonenes were obtained from Ms Michelle Mendell and Ms Jane Gifkins, Griffith University. All stock cultures were subcultured and maintained in nutrient broth at $4^{\circ} \mathrm{C}$.

\section{Evaluation of antimicrobial activity}

Antimicrobial activity of all plant extracts was determined using a modified disc diffusion assay. ${ }^{27,28}$ Briefly, $100 \mu \mathrm{L}$ of each bacterial culture was grown in $10 \mathrm{~mL}$ of fresh nutrient broth until they reached a count of $\sim 10^{8}$ cells $/ \mathrm{mL}$. A volume of $100 \mu \mathrm{L}$ of the bacterial suspension was spread onto nutrient agar plates and extracts were tested for antibacterial activity using $5 \mathrm{~mm}$ sterilised filter paper discs. Discs were infused with $10 \mu \mathrm{L}$ of the plant extracts, allowed to dry and placed onto the inoculated plates. The plates were allowed to stand at $4^{\circ} \mathrm{C}$ for $2 \mathrm{hr}$ before incubation at $37^{\circ} \mathrm{C}$ for $24 \mathrm{hr}$. The diameters of the inhibition zones were measured to the closest whole millimetre. Each assay was performed in at least triplicate. Mean values $( \pm$ SEM) are reported in this study. Standard discs of ampicillin $(10 \mu \mathrm{g})$ and chloramphenicol $(2 \mu \mathrm{g})$ were obtained from Oxoid, Australia and were used as positive controls to compare antibacterial activity. Filter discs infused with $10 \mu \mathrm{L}$ of distilled water (containing 1\% DMSO) were used as a negative control.

\section{Minimum inhibitory concentration (MIC) determination}

The minimum inhibitory concentration (MIC) of each extract against susceptible bacteria was determined as previously described. ${ }^{6,29}$ Briefly, the $B$. acerifolius extracts were diluted in deionised water (containing $1 \%$ DMSO) and tested across a range of concentrations. Discs were infused with $10 \mu \mathrm{L}$ of the test dilutions, allowed to dry and placed onto inoculated plates. The assay was completed as outlined above and graphs of the zone of inhibition versus concentration were plotted for each extract. Ln linear regression was used to determine the MIC values of each extract.

\section{Bacterial growth time course assay}

Bacterial growth time course studies were performed as previously described. ${ }^{30}$ Briefly, $3 \mathrm{~mL}$ of the $\log$ phase P. fluorescens and B. cereus bacterial cultures in nutrient broth were added individually to $27 \mathrm{~mL}$ nutrient broth containing $3 \mathrm{~mL}$ of $10 \mathrm{mg} / \mathrm{mL}$ methanolic leaf extract to give a final concentration of $1000 \mu \mathrm{g} / \mathrm{mL}$ in the assay. The tubes were incubated at $37^{\circ} \mathrm{C}$ with gentle shaking. The optical density was measured hourly at $550 \mathrm{~nm}$ for a $6 \mathrm{hr}$ incubation period. Control tubes were incubated under the same conditions but without the extract. All assays were performed in triplicate.

\section{Toxicity screening}

\section{Reference toxin for toxicity screening}

Potassium dichromate $\left(\mathrm{K}_{2} \mathrm{Cr}_{2} \mathrm{O}_{7}\right)$ (AR grade, Chem-Supply, Australia) was prepared as a $4 \mathrm{mg} / \mathrm{mL}$ solution in distilled water and was serially diluted in artificial seawater for use in the Artemia franciscana nauplii bioassay.

\section{Artemia franciscana nauplii toxicity screening}

Toxicity was tested using an adapted Artemia franciscana nauplii lethality assay ${ }^{31,32}$ Briefly, $400 \mu \mathrm{L}$ of seawater containing approximately 63 (mean 63.3, $n=75$, SD 11.3) A. franciscana nauplii were added to wells of a 48 well plate and immediately used for bioassay. A volume of $400 \mu \mathrm{L}$ of diluted plant extracts or the reference toxin were transferred to the wells and incubated at $25 \pm 1^{\circ} \mathrm{C}$ under artificial light (1000 Lux). A $400 \mu \mathrm{L}$ seawater negative control was run in triplicate for each plate. All treatments were performed in at least triplicate. The wells were checked at regular intervals and the number of dead were counted. The nauplii were considered dead if no movement of the appendages was detected within 10 sec. After $24 \mathrm{hr}$, all nauplii were sacrificed and counted to determine the total $\%$ mortality per well. The $\mathrm{LC}_{50}$ with $95 \%$ confidence limits for each treatment was determined using probit analysis.

\section{Statistical analysis}

Data are expressed as the mean \pm SEM of at least three independent experiments. One-way ANOVA was used to calculate statistical significance between control and treated groups with a $P$ value $<0.01$ considered to be statistically significant.

\section{RESULTS}

\section{Liquid extraction yields and qualitative phytochemical screening}

Extraction of $1 \mathrm{~g}$ of dried and powdered B. acerifolius leaves and flowers with methanol yielded $320 \mathrm{mg}$ and $375 \mathrm{mg}$ respectively (Table 1 ). The dried extracts were resuspended in $10 \mathrm{~mL}$ of deionised water (containing $1 \%$ DMSO), resulting in 32 and $37.5 \mathrm{mg} / \mathrm{mL}$ concentrations respectively. Qualitative phytochemical studies showed that both the leaf and flower extracts similar phytochemical profiles. Both contained high levels of polyphenolics, saponins and phytosterols, moderate levels of flavonoids, as well as low levels of triterpenpoids and tannins. 


\section{Antimicrobial activity}

To determine the growth inhibitory activity of the $B$. acerifolius leaf and flower extracts against the panel of pathogenic bacteria, aliquots $(10 \mu \mathrm{L})$ of each extract were screened in the disc diffusion assay. The B. acerifolius leaf extract inhibited the growth of several gram negative bacterial species (Figure 2). Of the $10 \mathrm{~g}$ negative bacterial strains tested, 5 (50\%) were inhibited by the methanolic B. acerifolius leaf extract. A. faecalis, $P$. fluorescens and $S$. newport were most susceptible to the $B$. acerifolius leaf extract, with ZOIs of $16.7,18.2$ and $14 \mathrm{~mm}$ respectively. The inhibition of these bacteria by this extract was similar or better than the inhibition by the positive controls ampicillin and chloramphenicol. Strong activity was also recorded against K. pneumonia and $S$. sonnei, each with $10 \mathrm{~mm}$ ZOIs. In contrast, the flower extracts were completely ineffective against all gram negative bacterial species. Similarly, the $B$. acerifolius leaf extract was much more effective than the flower extract against a panel of gram positive bacteria (Figure 3). The leaf extract was particularly potent against $S$. aureus, with a ZOI of $16.6 \mathrm{~mm}$ measured. In contrast, a $7.2 \mathrm{~mm}$ ZOI was measured for the flower extract against the same bacterium. The leaf extract was also a good inhibitor of B. cereus and S. pyogenes, with ZOIs of 9.6 and $8.2 \mathrm{~mm}$ respectively. These results are comparable to the inhibition seen for the ampicillin and chloramphenicol controls. In contrast, all extracts were completely ineffective against a panel of fungi (Figure 4).

The antimicrobial efficacy was further quantified by determining the MIC values for each extract against the microbial species which were determined to be susceptible. The B. acerifolius leaf extracts were good growth inhibitors of several bacterial species, although the flower extracts were only effective against the gram positive bacteria (as judged by MIC; Table 2). P. fluorescens was the most susceptible bacteria to the B. acerifolius leaf extract leaf extracts, with an MIC value of $25 \mu \mathrm{g} / \mathrm{mL}$ (approximately $0.25 \mu \mathrm{g}$ infused into the disc). The MIC values determined for the leaf extract against A. faecalis $(76 \mu \mathrm{g} / \mathrm{mL})$, S. newport $(84 \mu \mathrm{g} / \mathrm{mL})$ and $B$. cereus $(58 \mu \mathrm{g} / \mathrm{mL})$ are also indicative of potent growth inhibition. The MIC values of the leaf extract against K. pneumonia, S. sonnei, S. aureus and $S$. pyogenes were also $<1000 \mu \mathrm{g} / \mathrm{mL}$ and therefore also indicate

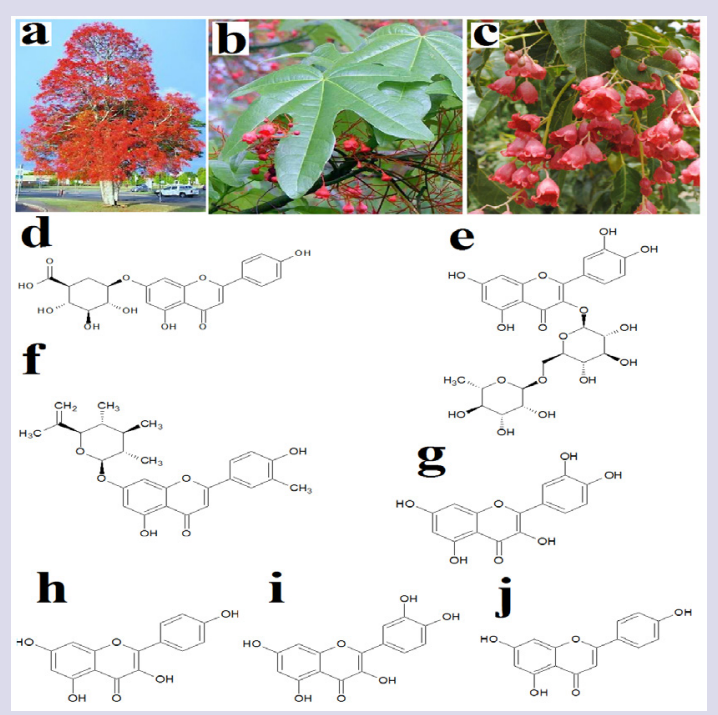

Figure 1: B. acerifolius (a) whole tree, (b) leaves and (c) flowers, as well as the chemical structures of (d) apigenin-7-O-glucuronide, (e) rutin, (f) luteolin-7-O-b-D-glucuronide, (g) quercetin, (h) kaempferol, (i) luteolin, (j) apigenin. ${ }^{23}$ good growth inhibitory activity. In contrast, the flower extract only inhibited the growth of the gram-positive bacteria and the MIC values $(>1000 \mu \mathrm{g} / \mathrm{mL})$ indicate only moderate growth inhibitory activity.

\section{Bacterial growth time course assay}

The most susceptible gram negative ( $P$. fluorescens) and gram positive (B. cereus) bacterial species were selected for further study by growth time course assays in the presence and absence of the leaf extract. Only the effect of the leaf extract on the bacterial growth time courses was evaluated as this extract was generally the most potent extract at inhibiting bacterial growth. The starting concentration of the extract used in these assays was $1000 \mu \mathrm{g} / \mathrm{mL}$. The methanolic B. acerifolius leaf extract significantly inhibited $P$. fluorescens (Figure 5a) and B. cereus (Figure 5b) growth within $1 \mathrm{~h}$, indicating a rapid antimicrobial action. Notably, the growth of both bacterial species was inhibited for the entire growth timecourse, indicating that the growth inhibition of these bacteria may be bacteriocidal at the concentrations tested against these bacteria.

\section{Quantification of toxicity}

The toxicity of the $B$. acerifolius leaf and flower extracts was initially tested in the Artemia franciscana nauplii bioassay at a concentration of $2000 \mu \mathrm{g} / \mathrm{mL}$ (Figure 6 ). Both extracts induced $>50 \%$ mortality at 24 , 48 and $72 \mathrm{hr}$ and were thus deemed to be non-toxic. The potassium dichromate positive control also induced mortality within $4 \mathrm{~h}$ (results not shown), with $100 \%$ mortality induction seen by $24 \mathrm{hr}$. To further quantify the effect of toxin concentration on the induction of mortality, the extracts were serially diluted in artificial seawater to test across a range of concentrations in the Artemia nauplii bioassay (Table 2). For comparison, serial dilutions of potassium dichromate were also tested. All extracts were determined to be nontoxic, with $\mathrm{LC}_{50}$ values $>1000 \mu \mathrm{g} /$ $\mathrm{mL}$ following $24 \mathrm{hr}$ exposure. Extracts with an $\mathrm{LC}_{50}>1000 \mu \mathrm{g} / \mathrm{mL}$ towards Artemia nauplii have previously been defined as being nontoxic. ${ }^{32}$

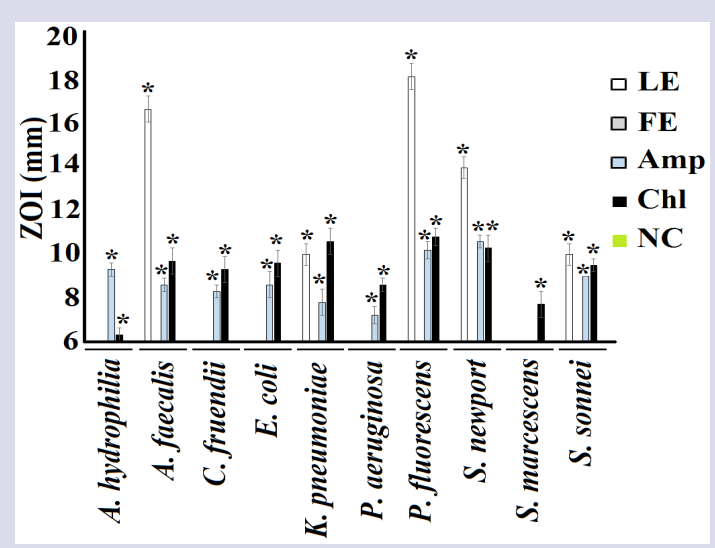

Figure 2: Antibacterial activity of $B$. acerifolius leaf and flower extracts and ampicillin $(10 \mu \mathrm{g})$ and chloramphenicol $(10 \mu \mathrm{g})$ controls measured as zones of inhibition $(\mathrm{mm})$ against Gram negative bacteria. $\mathrm{LE}=$ leaf extract; $\mathrm{FE}=$ flower extract; $\mathrm{Amp}=$ ampicillin; $\mathrm{Chl}=$ chloamphenicol. Results are expressed as mean \pm SEM of three determinations in triplicate $(n=9) .{ }^{*}$ indicates results that are significantly different to the untreated control $(p<0.01)$. 


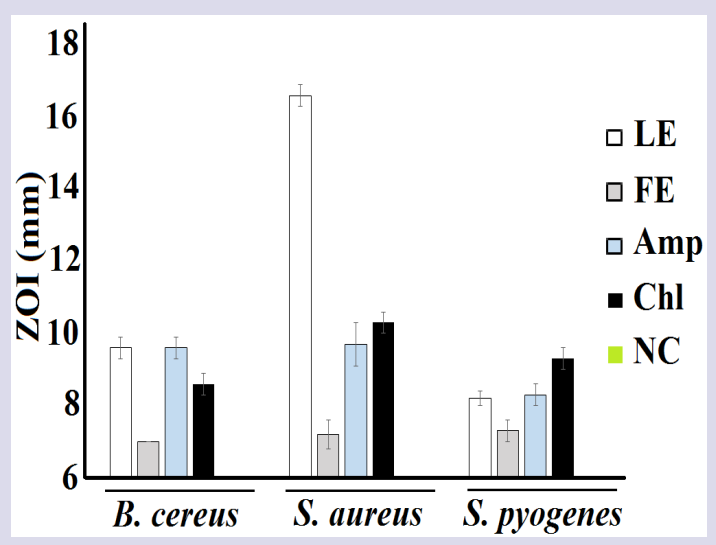

Figure 3: Antibacterial activity of $B$. acerifolius leaf and flower extracts and ampicillin $(10 \mu \mathrm{g})$ and chloramphenicol $(10 \mu \mathrm{g})$ controls measured as zones of inhibition $(\mathrm{mm})$ against Gram positive bacteria. LE = leaf extract; $\mathrm{FE}=$ flower extract; $\mathrm{Amp}=$ ampicillin; $\mathrm{Chl}=$ chloamphenicol. Results are expressed as mean \pm SEM of three determinations in triplicate $(n=9) .{ }^{*}$ indicates results that are significantly different to the untreated control $(p<0.01)$.

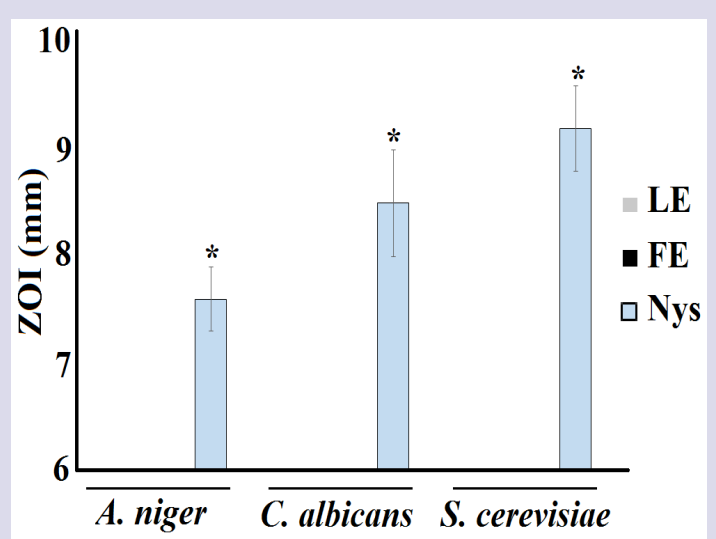

Figure 4: Antifungal activity of the B. acerifolius leaf and flower extracts and a nystatin control $(100 \mu \mathrm{g})$ measured as zones of inhibition $(\mathrm{mm})$. LE $=$ leaf extract; $\mathrm{FE}=$ flower extract; Nys = nystatin. Results are expressed as mean \pm SEM of three determinations in triplicate $(n=9)$. * indicates results that are significantly different to the untreated control $(p<0.01)$.

\section{DISCUSSION}

Recent increases in bacterial resistance has made the development of new antibiotic therapies a high priority. ${ }^{1,2}$ A concurrent decrease in the development of new antibiotic therapies has further increased this problem and new antibiotic therapies are urgently needed. Interest in re-evaluating medicinal plants for new antibiotic chemotherapies has increased substantially in recent years. Although we were unable to find evidence that $B$. acerifolius was also used for these purposes, the first Australians used several other Brachychiton spp. to treat multiple diseases and infections caused by bacterial pathogens. ${ }^{15,20}$ Furthermore, limited scientific evaluations have rigorously evaluated the antibacterial properties of B. acerifolius.

Our study examined the ability of $B$. acerifolius leaf and flower extracts to inhibit the growth of a panel of medicinally important bacterial pathogens. The B. acerifolius leaf extract was a particularly potent inhibitor of $P$. fluorescens with an MIC value of $25 \mu \mathrm{g} / \mathrm{mL}$. The leaf extract was also
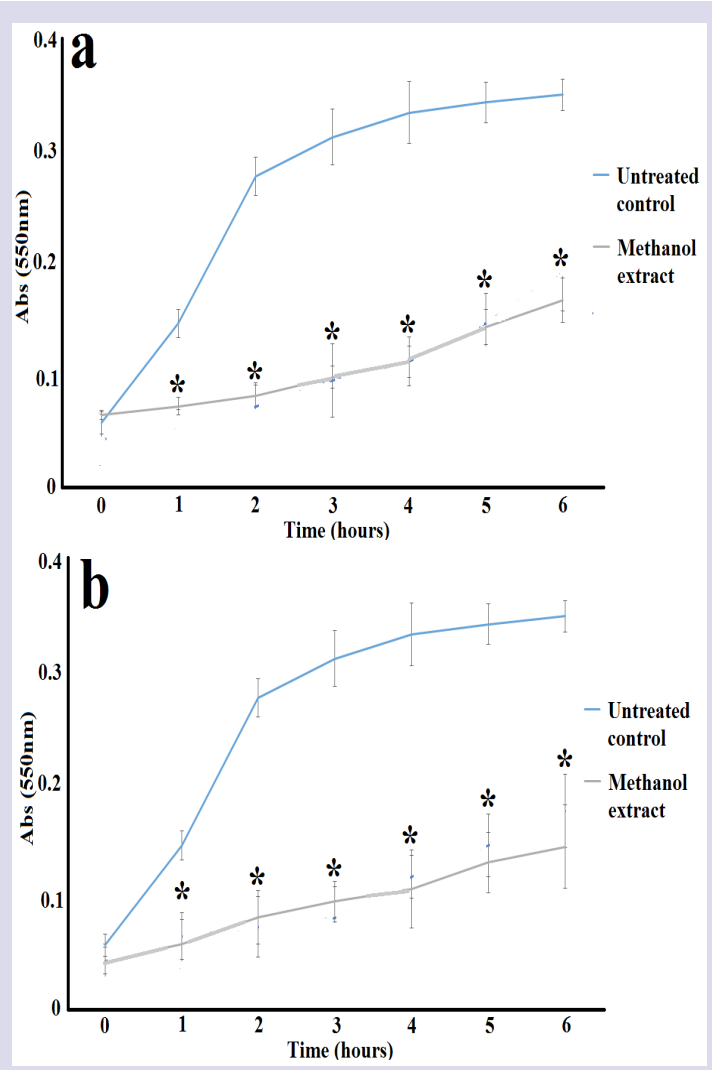

Figure 5: Bacterial growth curves for the $B$. acerifolius leaf extract against (a) P. fluorescens and (b) B. cereus. All bioassays were performed in at least triplicate and are expressed as mean \pm SEM. ${ }^{*}=$ growth results in the presence of the leaf extract that are significantly different to the untreated control growth $(p<0.01)$.

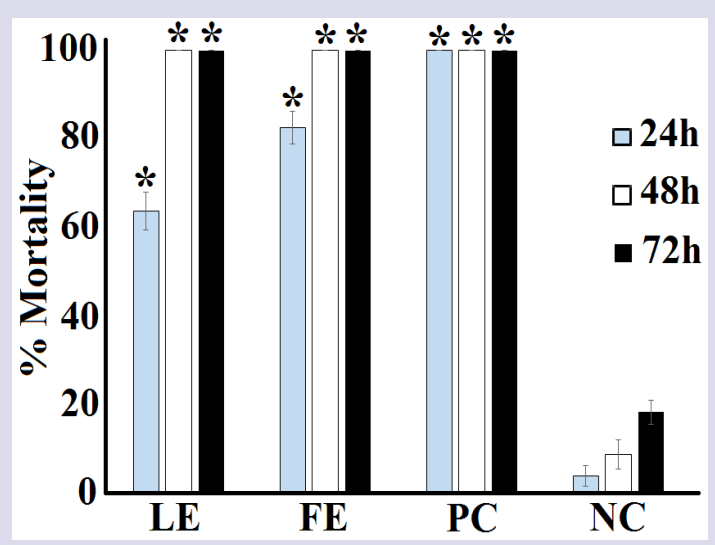

Figure 6: The lethality of the $B$. acerifolius leaf and flower extracts $(2000 \mu \mathrm{g} / \mathrm{mL})$, potassium dichromate $(1000 \mu \mathrm{g} / \mathrm{mL})$ and a seawater control. Blue bars represent the $\%$ mortality following $24 \mathrm{hr}$ exposure to the extract/toxin; white bars represent the \% mortality following $48 \mathrm{~h}$ exposure to the extract/toxin; black bars represent the \% mortality following $72 \mathrm{hr}$ exposure to the extract/toxin; NC = negative (seawater) control; $\mathrm{PC}=$ positive control $(1000 \mu \mathrm{g} / \mathrm{mL}$ potassium dichromate). All bioassays were performed in at least triplicate and are expressed as mean \pm SEM.* indicates results that are significantly different to the negative controls $(P<0.01)$. 
Table 1: The mass of dried extracted material, the concentration after resuspension in deionised water and qualitative phytochemical screenings of the $B$. acerifolius leaf extracts.

\begin{tabular}{|c|c|c|c|c|c|c|c|c|c|c|c|c|c|c|c|c|c|c|c|}
\hline \multirow{2}{*}{ 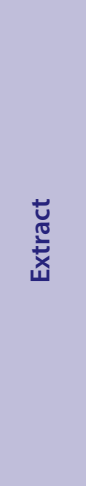 } & \multirow{2}{*}{ 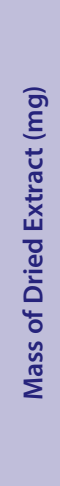 } & \multirow{2}{*}{ 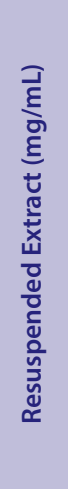 } & \multicolumn{3}{|c|}{$\begin{array}{l}\frac{n}{O} \\
\frac{C}{d} \\
\frac{c}{\alpha}\end{array}$} & \multicolumn{2}{|l|}{ 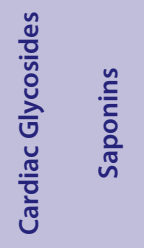 } & 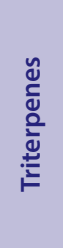 & \multicolumn{2}{|c|}{ 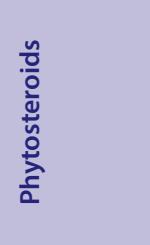 } & $\begin{array}{l}\frac{n}{\frac{n}{0}} \\
\frac{0}{0} \\
\frac{\underline{y}}{<}\end{array}$ & \multicolumn{2}{|r|}{$\begin{array}{l}\frac{n}{0} \\
\frac{0}{0} \\
\frac{0}{0} \\
\frac{0}{0} \\
\frac{\pi}{4}\end{array}$} & \multicolumn{2}{|c|}{ 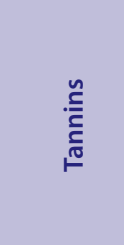 } & \multicolumn{3}{|c|}{ 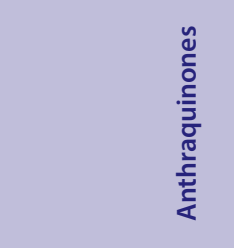 } & 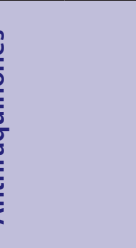 \\
\hline & & & 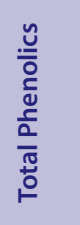 & $\begin{array}{l}\frac{0}{0} \\
\frac{3}{3} \\
\frac{1}{0} \\
\frac{1}{\pi} \\
3 \\
3\end{array}$ & 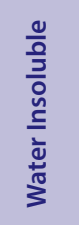 & 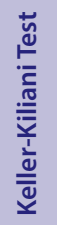 & 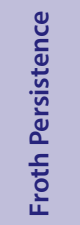 & 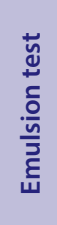 & 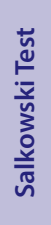 & 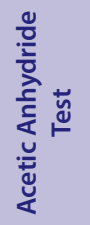 & 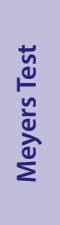 & $\begin{array}{l}\frac{n}{y} \\
\frac{n}{n} \\
\frac{n}{ \pm} \\
5 \\
\frac{\pi}{3}\end{array}$ & 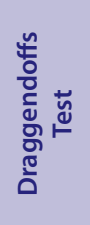 & 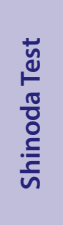 & 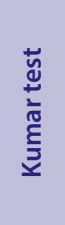 & 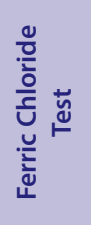 & 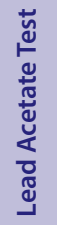 & 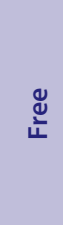 & 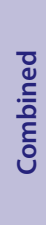 \\
\hline Leaf & 320 & 32.0 & +++ & +++ & +++ & - & +++ & ++ & + & +++ & + & - & - & ++ & ++ & ++ & + & - & - \\
\hline Flower & 375 & 37.5 & +++ & +++ & ++ & - & +++ & ++ & + & + & - & - & - & ++ & ++ & + & - & - & - \\
\hline
\end{tabular}

+++ indicates a large response; ++ indicates a moderate response; + indicates a minor response; - indicates no response in the assay.

a potent inhibitor of several bacterial pathogens associated with food poisoning and diarrhoea. Strong growth inhibitory activity was also noted for the B. acerifolius leaf extract against A. facealis (MIC $76 \mu \mathrm{g} /$ $\mathrm{mL}$ ), S. newport (MIC $84 \mu \mathrm{g} / \mathrm{L}$ ) and B. cereus (MIC $58 \mu \mathrm{g} / \mathrm{mL}$ ). The leaf extract was also a good inhibitor of K. pneumonnia (MIC $120 \mu \mathrm{g} / \mathrm{mL}$ ), $S$. sonnei $(183 \mu \mathrm{g} / \mathrm{mL})$, S. aureus $(672 \mu \mathrm{g} / \mathrm{mL})$ and S. spyogenes $(870 \mu \mathrm{g} / \mathrm{mL})$. Therefore, the leaf extract has potential for the treatment of diarrhoea and gastrointestinal disease.

The ability of the B. acerifolius leaf extract to inhibit the growth of both gram-positive and gram-negative bacteria is in agreement with previous reports of the antibacterial activity of other Australian plant species. ${ }^{33}$ In this study, the gram-negative and gram-positive bacteria were both susceptible to the B. acerifolius leaf extracts. In contrast, many previous studies have reported substantially greater susceptibility for gram-positive bacteria to South American, ${ }^{34}$ African ${ }^{11,12}$ and Australian ${ }^{33}$ plant extracts. Results within our laboratory have also confirmed the greater susceptibility of gram-positive bacteria towards many other Australian plant extracts. ${ }^{35,36}$ The gram-negative bacterial cell wall outer membrane is thought to act as a barrier to many substances including several antibiotics. ${ }^{37}$ In contrast, other studies have demonstrated that gramnegative bacteria are often as susceptible (or more susceptible) to plant extracts from different Australian plant species. ${ }^{38}$

Whilst a detailed investigation of the phytochemistry of the B. acerifolius leaf extracts was beyond the scope of our study, qualitative screening studies were used to determine the classes of compounds present. Both the leaf and flower extracts contained relatively high levels of total phenolics and saponins. It is likely that these and other phytochemical classes, may contribute to the growth inhibitory properties of these extracts. Our qualitative phytochemical screening studies also indicated that flavonoid, triterpenoids and phytosterols were present in the B. acerifolius leaf extract. Many studies have reported potent antibacterial activities for a wide variety of these compounds. ${ }^{24}$ Further phytochemical evaluation studies and bioactivity driven isolation of active components is required to further evaluate the mechanism of bacterial growth inhibition.

It is likely that other phytocompounds may also contribute to the antibacterial properties of the $B$. acerifolius extracts. Several monoterpenoids including $\alpha$-pinene, $\beta$-pinene, sabinene, mycrene, terpinene,
Table 2: Minimum bacterial growth inhibitory concentration $(\mu \mathrm{g} / \mathrm{mL})$ of the $B$. acerifolius leaf and flower extracts against susceptible bacterial species and the $\mathrm{LC}_{50}$ in the Artemia nauplii assay.

\begin{tabular}{|c|c|c|}
\hline \multirow[t]{2}{*}{ Bacterial species } & \multicolumn{2}{|c|}{ B. acerifilius Extrac } \\
\hline & LE & $\mathrm{FE}$ \\
\hline \multicolumn{3}{|l|}{ Gram negative } \\
\hline A. hydrophilia & - & - \\
\hline A. faecalis & 76 & - \\
\hline C. freundi & - & - \\
\hline E. coli & - & - \\
\hline K.pneumoniae & 120 & - \\
\hline P. aeruginosa & - & - \\
\hline P. fluroscens & 25 & - \\
\hline S. newport & 84 & - \\
\hline S. marcenscens & - & - \\
\hline S. sonnei & 183 & - \\
\hline \multicolumn{3}{|l|}{ Gram positive } \\
\hline B. cereus & 58 & 1220 \\
\hline S. aureus & 672 & 1853 \\
\hline S. pyogenes & 870 & 1025 \\
\hline \multicolumn{3}{|l|}{ Fungi } \\
\hline A. niger & - & - \\
\hline C. albicans & - & - \\
\hline S. pyogenes & - & - \\
\hline \multicolumn{3}{|c|}{ Artemia nauplii toxicity (LC50) } \\
\hline $24 \mathrm{hr}$ exposure & 1680 & 1247 \\
\hline
\end{tabular}

Numbers indicate the mean MIC values of triplicate determinations. - indicates no inhibition. 
limonene, piperitone and $\beta$-phellandrene inhibit the growth multiple bacteria. ${ }^{24}$ Antibacterial activities have also been reported for several sesquiterpenoids including a-cubebene, copaene and caryophyllene. ${ }^{24}$ The phytochemical studies described in this report did not test for these classes of compound. However, it is likely that they are present and that they may contribute to the antibacterial activity reported here. Tannins were also detected in our study. Interestingly, tannins have bacterial growth inhibitory activity against a broad panel of bacteria via a variety of mechanisms. ${ }^{39}$ Thus, it is likely that multiple compounds within the $B$. acerifolius extracts are contributing to the antibacterial activity reported here.

The findings of this study also demonstrate that the B. acerifolius extracts extracts were nontoxic towards Artemia franciscana nauplii, with $\mathrm{LC}_{50}$ values substantially $>1000 \mu \mathrm{g} / \mathrm{mL}$. Extracts with $\mathrm{LC}_{50}$ values $>1000 \mu \mathrm{g} /$ $\mathrm{mL}$ towards Artemia nauplii are defined as being nontoxic. ${ }^{32}$ Whilst our preliminary toxicity studies indicate that these extracts may be safe for therapeutic use, studies using human cell lines are required to further evaluate the safety of these extracts. Furthermore, whilst these studies have demonstrated the potential of the $B$. acerifolius extracts in the development of future antibiotic chemotherapeutics, more work is required to isolate the inhibitory components and determine the mechanism of inhibition.

\section{CONCLUSION}

The results of this study demonstrate the potential of the B. acerifolius extracts as inhibitors of pathogenic bacteria growth. Furthermore, their lack of toxicity indicates that they are safe for internal treatment. Further studies aimed at the purification and identification of bioactive components are required to examine the mechanisms of action of these agents.

\section{ACKNOWLEDGEMENT}

The authors are grateful to Michelle Mendell and Jane Gifkins for the gift of the clinical isolate bacterial strains. Financial support for this work was provided by the Environmental Futures Research Institute and the School of Natural Sciences, Griffith University, Australia.

\section{CONFLICT OF INTEREST}

The authors report no conflicts of interest.

\section{ABBREVIATIONS}

DMSO: Dimethyl sulfoxide; $\mathbf{L C}_{50}:$ The concentration required to achieve $50 \%$ mortality; MIC: Minimum inhibitory concentration.

\section{REFERENCES}

1. Cheesman MJ, llanko A, Blonk B, et al. Developing new antimicrobial therapies: Are synergistic combinations of plant extracts/compounds with conventional antibiotics the solution?. Pharmacogn Rev. 2017;11(22):57-72. DOI: 10.4103/ phrev.phrev_21_17

2. WHO. Antimicrobial Resistance. World Health Organization. 2016. Available from: http://www.who.int/mediacentre/factsheets/fs194/en/. [Cited on 2017 May 10]

3. Cowan MM. Plant products as antibacterial agents. Clin Microbiol Rev. 1999;12(4):564-82

4. Bhavnani SM, Ballow CH. New agents for Gram-positive bacteria. Curr Opin Microbiol. 2000;3(5):528-34

5. Chiariandy $\mathrm{CM}$, Seaforth $\mathrm{CE}$, Phelps $\mathrm{RH}$, et al. Screening of medicinal plants from Trinidad and Tobago for antimicrobial and insecticidal properties. J Ethnopharmacol. 1999;64(3):265-70

6. Hart C, Ilanko P, Sirdaarta J, et al. Tasmannia stipitata as a functional food/ natural preservative: Antimicrobial activity and toxicity. Pharmacogn Commun. 2014;4(4):33-47. DOI: 10.5530/pc.2014.4.4

7. Wright $\mathrm{MH}$, Arnold MSJ, Lee CJ, et al. Qualitative phytochemical analysis and antibacterial activity evaluation of Indian Terminalia spp. against the pharyn- gitis causing pathogen Streptococcus pyogenes. Pharmacogn Commun. 2016;6(2):85-92. DOI: 10.5530/pc.2016.2.6

8. Hübsch Z, Zyl RLV, Cock IE, et al. Interactive antimicrobial and toxicity profiles of conventional antimicrobials with Southern African medicinal plants. S Afr J Bot. 2014;93:185-97. DOI: 10.1016/j.sajb.2014.04.005

9. Arkhipov A, Sirdaarta J, Rayan P, et al. An examination of the antibacterial antifungal, anti-Giardial and anticancer properties of Kigelia africana fruit extracts. Pharmacogn Commun. 2014;4(3):62-76. DOI: 10.5530/pc.2014.3.7

10. Rabadeaux $C$, Vallette $L$, Sirdaarta J, et al. An examination of the antimicrobial and anticancer properties of Khaya senegalensis (Desr.) A Juss. bark extracts. Pharmacogn J. 2017:9(2):175-84. DOI: 10.5530/pj.2017.4.82

11. Cock IE, van Vuuren SF. Anti-Proteus activity of some South African medicinal plants: Their potential for the treatment and prevention of rheumatoid arthritis. Inflammopharmacol. 2014;22(1):23-36. DOI 10.1007/s10787-013-0179-3

12. Cock IE, Vuuren VSF. The potential of selected some South African plants with anti-Klebsiella activity for the treatment and prevention of ankylosing spondylitis. Inflammopharmacol. 2015;23(1):21-35. DOI: 10.1007/s-10787-0130179-3

13. Mohanty S, Cock IE. Evaluation of the antibacterial activity and toxicity of Myrciaria caulifloria methanolic leaf and fruit extracts. Int $\mathrm{J}$ Microbiol. 2009;7(2):1-8

14. Paz EA, Cerdeiras MP, Fernandez J, et al. Screening of Uruguayan medicinal plants for antimicrobial activity. J Ethnopharmacol. 1995;45(1):67-70.

15. Cock IE. Medicinal and aromatic plants-Australia. In Ethnopharmacology, Encyclopedia of Life Support Systems (EOLSS). 2011. Developed under the auspices of UNESCO. Oxford, UK: EOLSS Publishers. 2011. Available from: http://www. eolss.net.

16. Sirdaarta J, Matthews B, Cock IE. Inhibitory activity of Kakadu plum fruit extracts against microbial triggers of rheumatoid arthritis: Identification of stilbene and tannin components. J Funct Foods. 2015;17:610-20. DOI: 10.1016/j. jff.2015.06.019

17. Winnett $V$, Sirdaarta J, White $A$, et al. Inhibition of Klebsiella pneumonia growth by selected Australian plants: Natural approaches for the prevention and management of ankylosing spondylitis. Inflammopharmacol. 2017;25(2):22335. DOI: 10.1007/s10787-017-0328-1

18. Wright $\mathrm{MH}$, Matthews B, Arnold MSJ, et al. The prevention of fish spoilage by high antioxidant Australian culinary plants: Shewanella putrefaciens growth inhibition. Int J Food Sci and Technol. 2016;51(3):801-13. DOI: 10.1111/ijfs.13026

19. Ilanko A, Cock IE. The interactive antimicrobial activity of conventional antibiotics and Petalostigma spp. Extracts against bacterial triggers of some autoimmune inflammatory diseases. Pharmacogn J. 2019;11(2):292-309. DOI: 10.5530/pj.2019.11.45

20. Lassak EV, McCarthy TM. Australian medicinal plants. A complete guide tom identification and usage. Reed New Holland Publishers, Sydney Australia. 2011.

21. Salem MZ, Ali HM, Mansour MM. Fatty acid methyl esters from air-dried wood, bark and leaves of Brachychiton diversifolius $\mathrm{R}$. Br: Antibacterial, antifungal and antioxidant activities. Bioresources. 2014;9(3):3835-45.

22. Mpala L, Chikowe G, Cock IE. Brachychiton rupestris (T.Mitch. ex Lindl.) K. Schum. Extracts inhibit the growth of Streptococcus pyogenes. Pharmacogn Commun. 2019;9(1):27-33. DOI: 10.5530/pc.2019.1.6

23. Zeid AH, Farag MA, Hamed MA, et al. Flavonoid chemical composition and antidiabetic potential of Brachychiton acerifolius leaves extract. Asian Pac J Trop Biomed. 2017:7(5):389-96.

24. Cock IE. The phytochemistry and chemotherapeutic potential of Tasmania lanceolata (Tasmanian pepper): A review. Pharmacogn Commun. 2013:3(4):1-13. DOI: $10.5530 /$ pc.2013.4.3

25. Kalt FR, Cock IE. Gas chromatography-mass spectroscopy analysis of bioactive Petalostigma extracts: Toxicity, antibacterial and antiviral activities. Pharmacogn Mag. 2014;10 (Suppl 1):S37-49. DOI: 10.4103/0973-1296.127338

26. Vesoul J, Cock IE. The potential of Bunya nut as an antibacterial food agent Pharmacogn Commun. 2012;2(1):72-9. DOI: 10.5530/pc.2012.1.13

27. Wright $\mathrm{MH}$, Shalom J, Matthews $\mathrm{B}$, et al. Terminalia ferdinandiana Exell: Extracts inhibit Shewanella spp. growth and prevent fish spoilage. Food Microbiol. 2019;78:114-22. DOI: 10.1016/j.fm.2018.10.006

28. Cock IE. Antimicrobial activity of Callistemon citrinus and Callistemon salig nus methanolic extracts. Pharmacogn Commun. 2012;2(3):50-7. DOI: 10.5530/ pc.2012.3.11

29. Cock IE, Winnett V, Sirdaarta J, et al. The potential of selected Australian medicinal plants with anti-Proteus activity for the treatment and prevention of rheumatoid arthritis. Pharmacogn Mag. 2015;11(Suppl 1):S190-208. DOI: 10.4103/09731296. 157734

30. Bryant K, Cock IE. Eupomatia laurina R.Br. fruit solvent extractions inhibit the growth of a panel of pathogenic bacteria. Pharmacogn Commun. 2017:7(1):16 23. DOI: $10.5530 /$ pc.2017.1.3

31. Ruebhart DR, Wikramasinghe WA Cock IE. Protective efficacy of the antioxidants vitamin $\mathrm{E}$ and Trolox against Microcystis aeruginosa and microcystin-LR in Artemia franciscana nauplii. J Toxicol Environ Health Part A. 2009;72(24):156775

32. Cock IE, Ruebhart DR. Comparison of the brine shrimp nauplii bioassay and the 
ToxScreen-II test for the detection of toxicity associated with Aloe vera (Aloe barbadensis Miller) leaf extract. Pharmacogn Res. 2009;1(2):98-101.

33. Cock IE. Antibacterial activity of selected Australian plant species. The Int $J$ Microbiol. 2008;6:2.

34. Mohanty S, Cock IE. Evaluation of the antibacterial activity and toxicity of Myrciaria caulifloria methanolic leaf and fruit extracts. Int J Microbiol. 2009;7(2):1-8.

35. Cock IE. Antimicrobial activity of Eucalyptus major and Eucalyptus baileyana methanolic extracts. Int J Microbiol. 2009;6(1).

36. Chikowe G, Mpala L, Cock IE. Antibacterial activity of selected Australian
Syzygium species. Pharmacogn Commun. 2013;3(4):77-83. DOI: 10.5530/ pc.2013.4.11

37. Tortora GJ, Funke BR, Case CL. Microbiology: An Introduction, Benjamin Cummings, San Francisco. 2001.

38. Cock IE. Antimicrobial activity of Acacia aulacocarpa and Acacia complanta methanolic extracts. Pharmacogn Commun. 2012;2(1):66-71. DOI: 10.5530/ pc.2012.1.12

39. Buzzini P, Arapitsas P, Goretti M, et al. Antimicrobial activity of hydrolysable tannins. Mini-Rev Med Chem. 2008;8(12):1179-87.

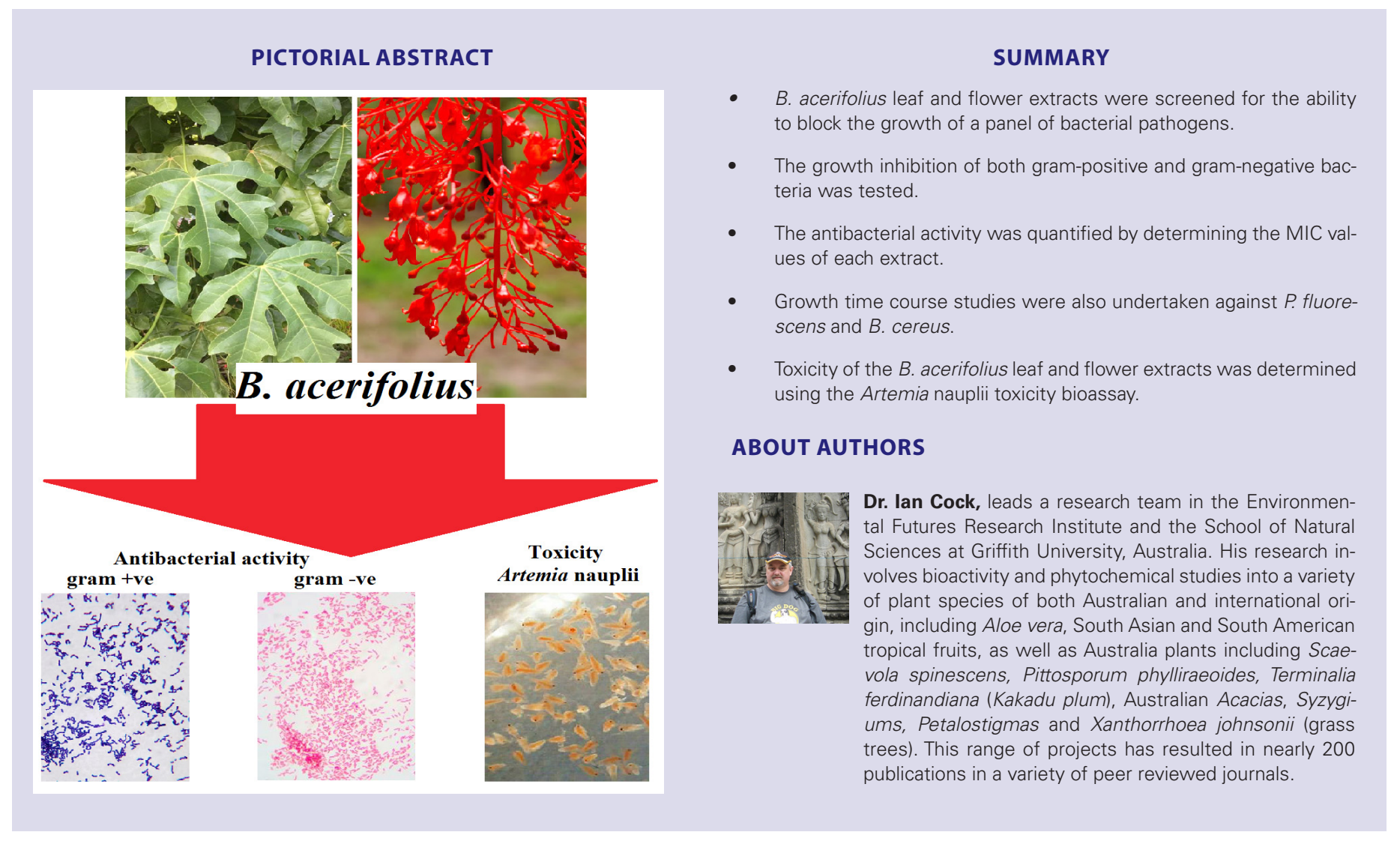

